\section{Painless ascites in systemic lupus erythematosus}

Ascites may occur in systemic lupus erythematosus in association with bacterial peritonitis ${ }^{1}$ or secondary to major intestinal complications, such as infarction or ulceration. ${ }^{2}$ In these circumstances pain is a predominant symptom. Painless ascites may complicate the nephrotic syndrome, congestive heart failure, or hepatic cirrhosis, but its occurrence as a presenting feature without involvement of these organs is unreported. ${ }^{3}$ We describe two cases of systemic lupus where the presenting feature was painless ascites which was not secondary to disease of heart, lung, or kidney.

\section{Case histories}

Case 1-A 29-year-old Italian housewife developed considerable swelling of the abdomen, which persisted for one month until a laparotomy was performed. At operation three litres of clear, straw-coloured ascites was drained but no abnormality of viscera or peritoneum was found. The fluid contained few lymphocytes and bacterial cultures including those for acid-fast bacilli were negative. After two months ascites recurred, and at a second

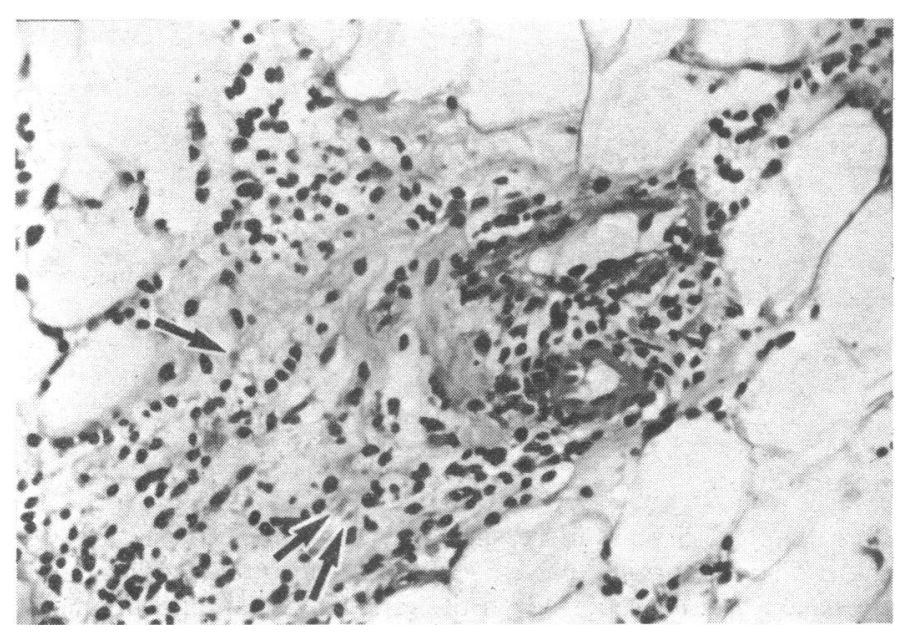

H\&E section of peritoneal biopsy from patient $(2)(\times 208)$ showing inflammatory cell infiltrate with haematoxylin bodies (arrowed).

laparotomy a further three litres of sterile ascitic fluid was drained. She was then referred to this hospital where examination showed a thin, apyrexial woman with generalised lymphadenopathy. Ascites was not detectable clinically or by paracentesis at this time, and there were no other abnormal physical findings. The results of numerous routine investigations were normal, but the serum antinuclear factor was appreciably raised (1600 units ; normal $<1$ unit) and the diagnosis of systemic lupus was confirmed by the presence of numerous LE cells in the peripheral blood. The patient subsequently developed pleuritic chest pain and for the first time lower abdominal discomfort. Investigations now showed anaemia, leucopenia, and a raised ESR. Treatment with prednisolone was followed by relief of symptoms and return to normal of haemoglobin, white cell count, and ESR. Prednisolone was subsequently reduced and the patient is now home and in good health ten months later.

Case 2-An 11-year-old Egyptian girl developed considerable ascites and leg oedema over a five day period. Treatment with chlorthalidone and prednisolone was ineffective and a right-sided pleural effusion developed.
After three months without improvement she was referred to this hospital, where examination showed gross tense ascites and leg oedema. There was no evidence of constrictive pericarditis or congestive heart failure. The results of investigations showed haemoglobin $11.6 \mathrm{~g} / \mathrm{dl}$; white cell count $11 \times 10^{9} / 1$; ESR $80 \mathrm{~mm}$ in one hour. Plasma urea was $8.0 \mathrm{mmol} / 1$ (normal $2.5-6.5 \mathrm{mmol} / \mathrm{l}$ ); glomerular filtration rate $38 \mathrm{ml} / \mathrm{min}$; there was no proteinuria. The plasma concentrations of albumin was $20 \mathrm{~g} / 1$ and globulin $33 \mathrm{~g} / 1$; other tests of liver function including liver biopsy were normal. DNA binding was raised both in plasma $68 \%$ (normal $0-30 \%$ ) and ascitic fluid $57 \%, \mathrm{C}_{3}$ component of complement in plasma was reduced at $29 \%$ (normal $68-110 \%$ ) and cryoglobulins were present in serum. Cytology and culture of the ascitic fluid produced negative findings. LE cells were not found in the peripheral blood but skin biopsy showed linear aggregation of immunoglobulin along the basement membrane characteristic of systemic lupus. ${ }^{4}$ Barium studies of large and small bowel showed normal findings, as did biopsies of jejunum and rectum. At peritoneoscopy ascites was confirmed and the omental serosa showed discrete areas of hyperaemia with nodules, biopsy of one of these areas showed a considerable inflammatory reaction with many haematoxylin bodies (fig). SLE was diagnosed and treatment was started with oral prednisolone, $40 \mathrm{mg}$ daily. Despite improvement in biochemical and immunological indices, the ascites did not lessen and required drainage on four occasions (total volume 52 litres). The ascites was eventually controlled with systemic frusemide, spironolactone, prednisolone, and cyclophosphamide and intraperitoneal triamcinolone. On discharge the patient was well and no ascites was clinically detectable. The ascites has not recurred after a further four months' treatment.

\section{Discussion}

The two cases described here show that SLE may present as painless ascites in the absence of any bowel lesion and without major disease of heart, liver, or kidney. In the first case ascites required drainage on two occasions and cardiac, hepatic, and renal function were normal. In the second case glomerular filtration was reduced but there was no oliguria or proteinuria; the ascites was almost certainly due to peritoneal serositis and not related to the mild renal dysfunction.

In an extensive review of systemic lupus Dubois ${ }^{3}$ stated that ascites did not occur other than secondary to the disorders mentioned above. In both our patients reported here ascites most probably accumulated secondary to peritoneal serositis. The possibility of SLE should be considered in the differential diagnosis of painless ascites even though other well-recognised clinical features of the disease are absent.

We thank Professor C C Booth for permission to publish these cases; Dr V Chadwick for his constructive criticism; Dr J Uff for the photomicrograph; and Ms J de Luca for typing the manuscript.

${ }^{1}$ Lipskey, P E, et al, Fournal of the American Medical Association, 1975, 232, 929.

2 Sleisenger, M H, and Fordtran, J S, Gastrointestinal Disease. Philadelphia, Saunders, 1973.

3 Dubois, E L, Lupus Erythematosus. University of Southern California Press, 1974.

${ }^{4}$ Percy, J S, and Smith, C J, fournal of the American Medical Association, 1969, 208, 485.

(Accepted 15 March 1977)

Department of Medicine, Hammersmith Hospital and Royal Postgraduate Medical School, London W12 OHS

P E JONES, MSC, MRCP, honorary senior registrar

P RAWCLIFFE, MB, MRCP, senior house officer (present address: United Oxford Hospitals)

N WHITE, BSC, MRCP, senior house officer

A W SEGAL, MD, MRCP, honorary senior registrar (present address : Clinical Research Centre, Harrow, Middx) 